Agro-Science Journal of Tropical Agriculture, Food, Environment and Extension Volume 18 Number 2 (May 2019) pp. 51-58

ISSN 1119-7455

\title{
SOCIOECONOMIC AND PROFITABILITY ANALYSIS OF CATFISH PRODUCTION: A CASE STUDY OF NSUKKA LOCAL GOVERNMENT AREA OF ENUGU STATE, NIGERIA
}

\author{
Onyekuru N.A., Ihemezie E.J. and Chima C.C.
}

Food Security and Sustainable Environment Research

Group Environment and Development Research Unit

Department of Agricultural Economics, University of Nigeria, Nsukka

Corresponding author's email: eberechukwu.ihemezie@unn.edu.ng

\begin{abstract}
This study examined the economics of catfish production in Nigeria using Nsukka Local Government Area of Enugu State, Nigeria as a case study. To achieve the study objectives, 40 catfish producers were randomly sampled and data for the study were collected with the aid of questionnaires. Descriptive statistics and net farm income analysis were employed for the analysis of the data collected. The study findings show that most (85\%) of the catfish farmers were males, and majority of them are in their active ages ( $<35$ to 55 years). About 20\% of the total population sampled was involved in full time catfish farming and $80 \%$ were able to finance their catfish farm from personal savings. Majority of the respondents have rich experience in catfish farming and have attained some level of education which is expected to influence their output positively. The total cost of catfish production was estimated to be $\$ 584,968.041$ (\$1,614.73) per production cycle (average 7 months), and the total revenue generated from the sale of market size catfish in the study area was $\$ 2,257,098$ (\$6,226.48) per production cycle. The respondents made a net farm income of \$1,672,129.96 $(\$ 4,615.70)$ in one production cycle (average 7 months). This indicates that catfish production is profitable in the area. To enhance the performance of catfish production, the study recommends improvement in infrastructural facilities that will create an enabling environment for increased productivity and profitability.
\end{abstract}

Key words: catfish; production; profitability, socio-economic factors

\section{INTRODUCTION}

In the recent times, the increasing human population in the face of inelastic production strategies appears to have widened the demand and supply gap of agricultural products, especially protein-based foods (Igwe and Onyekwere, 2007). According to Cheeke (2002), the global demand for protein-based foods will increase by $58 \%$ between 1995 and 2020, and that consumption will rise in the year 2020.This implies that to ensure food nutrition security, there is need to increase the production of protein-based foods. This is more pertinent in developing countries where malnutrition and food insecurity is very common, and this is where production of fish products comes in as a panacea to protein-based nutrition deficiency. Fishing like other hunting activities has been a major source of food for the human race and has contributed to the reduction of the unsavory outbreak of anemia, kwashiorkor and other ailments due to malnutrition (Olagunje et al., 2007). This is because fish has a nutrient profile superior to most terrestrial meats (beef, pork and chicken, etc). It is an excellent source of high quality animal protein and highly digestible energy (Kudi et al., 2008). According to Ali et al. (2008), fish is the most important animal protein food available in the tropics. It provides about $40 \%$ of the dietary intake of animal protein of the average Nigerian (Federal Department of Fisheries, FDF, 2007). In addition to its nutritional benefits, fish is important for animal feed, and serves as a source of raw materials for allied industries (Esu et al., 2009). Furthermore, fish farming contributes about one-third of the Gross Domestic Product (GDP) in Nigeria (Amao et al., 2009). The fishery sub-sector provides full-time employment to over 12 million people, which constitutes about $3 \%$ of the active population of the nation; another 11 million people indirectly earn their livelihoods from activities related to fisheries (FAO, 1991; Olagunje et al., 2007). However, despite the huge potentials of fish farming, Nigeria is still one of the largest importers of fish in the developing world. According to the Central Bank of Nigeria (2017), Nigeria spends over 288 billion naira on annual fish importation. 
Nigerians are large consumers of fish with a demand estimate at 1.4 million metric tons. However, a demand supply gap of at least 0.7 million metric tons exists nationally with import making up the short fall at a cost of almost 0.5 billion US dollars per year (Kudi et al., 2008). Domestic fish production of about 1.1million metric tons is supplied by artisan fishermen, despite over fishing in many water bodies across the country (Adekoya and Miller, 2004). It is therefore suggested that Nigerians must turn to their underutilized inland water for improved fish production and aquaculture. The most commonly cultured species of fish in Nigeria include catfish, tilapia and carp. However, many fish farmers in Nigeria focus on catfish (Clarias gariepinus) because of how well it adapts to the environment, its hardy nature that allows it to be easily retailed live, and its premium market price. Since the culture of Clarias gariepinus through hormonal induction (hypophysation) was initiated in Western Nigeria in 1973, the procedure has been widely practiced throughout Nigeria, thus leading to the increase of farm raised catfish from 1980s till date (Iheke and Nwagbara, 2010). African catfish, clarias gariepinus, clarias anguillaris, Heterobranchus bidorsalis, Clarias longifilis and their hybrids are cultivated for reasons of their high growth rates, disease resistance and amenability of high density culture, related to their air breathing habits (Fagbenro et al., 1993; Miller and Atanda, 2007).

Catfish is suitable for stocking in ponds and they tolerate low dissolved oxygen better than other common species in the country. Farm raised catfish is a good source ( $15 \%$ by weight) of high quality protein, and it has essentially no carbohydrate or fiber. The fat content is low compared to other animal meat. The cholesterol level and caloric value of catfish are also low with other desirable qualities such as fatty acids, mineral and vitamin content which makes the catfish an exclusively desirable recipe for those on fat and calorie controlled diets. Besides, catfish has wide acceptability as food in Nigeria. Despite these considerably high potentials, local fish production has failed to meet the country's domestic demand (Oladimeji, 2017). This has led to the existence of a demand-supply gap of at least 0.7 million metric tons in Nigeria. Increased catfish production in the country, according to FAO (2005), can help reduce this worrisome demand supply fish gap in the nation. Ugwumba and Chukwuji (2010) suggested that greater improvement in catfish production can be achieved with proper analysis that will lead to the knowledge of the level of profitability of catfish farming and the socio-economic features of catfish farmers that constrain maximum production.

Few previous studies have attempted to examine the reasons for the low level production of catfish currently experienced in Nigeria. For instance, Ugwumba and Nnabuife (2008), Adeogun et al. (2007) and Ugwumba et al. (2006) all linked the low level of catfish production in Nigeria to inadequate supplies from the local catfish farmers due to the use of poor quality catfish seeds, inadequate information, high cost of feeds, traditional techniques, small size of holdings, poor infrastructural facilities and low capital investment. But none of the studies analyzed the profitability of the catfish business. Greater improvement in catfish production can be achieved with a proper analysis that will lead to knowledge of the level of profitability of catfish farming and constraints to production which constitute the basis for this study.

There is an increase quest for job security and profit making in agribusiness among the labour force in Nigeria. Despite the potentials in agribusiness, farmers still employ insufficient practices in production which result to economic losses, and this practice is not uncommon among catfish farmers. Catfish profitability still remains a key factor that determines the long survival of the production business. There are farmers who tend to venture in catfish production with limited information on the prospects and challenges involved in the production enterprise. Some producers run at loss or out of business after few years of establishment due to insufficient planning, budgeting and execution of the production plan, and without proper knowledge about the profitability of the agribusiness they are venturing into. The aim of this study therefore, is to bridge the existing gap as regards the profitability and general prospects of catfish farming in Nigeria. This will enable both practicing catfish farmers and prospective farmers to increase the productivity and profitability of their businesses. To this end, this, study seeks to: i) examine the socio-economic characteristics of catfish producers, ii) ascertain catfish management systems and practices, and iii) estimate costs and returns of catfish production, using Nsukka Local Government Area (LGA) of Enugu State, Nigeria as a case study.

\section{MATERIALS AND METHODS}

The study was carried out in Nsukka Local Government Area of Enugu State, Nigeria, which is one of the Local Government Areas in Nsukka Agro-ecological zone (Figure 1), (Enugu State Agricultural Development Programme [ENADEP], 2008). The location was chosen for the study because of the high predominance of catfish farming in the area. This area comprises of 18 communities. It is bounded by Uzo-Nwani, Igbo Etiti, Isi-Uzo, Udenu and Igbo Eze South Local Government Areas. Nsukka Local Government Area is located between latitudes $6^{\circ} 30^{\prime}$ and $7^{\circ} 6^{\prime}$ north and longitudes $6^{\circ} 54^{\prime}$ and $7^{\circ} 54^{\prime}$ east. The study area covers about $463 \mathrm{~km}^{2}$ with an estimated population of about 2,755,865 (Federal Office of 


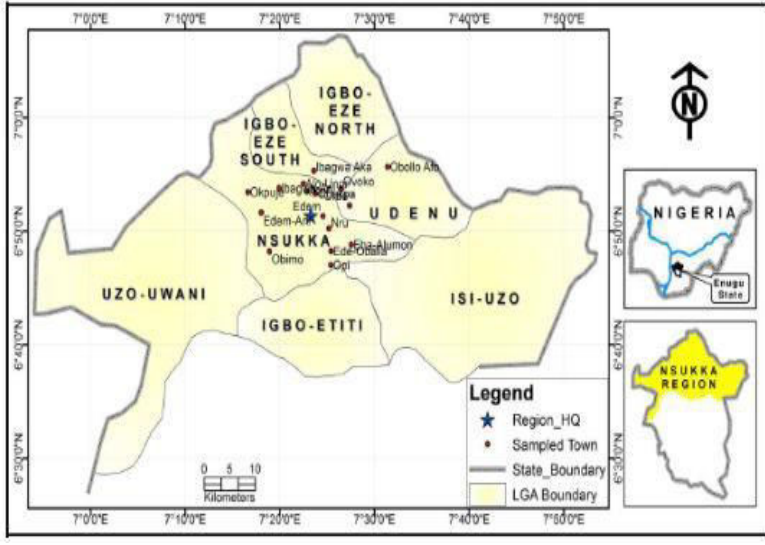

Figure 1: Map of Nsukka Agro-ecological zone showing sampled area in Nsukka Local Government Area. Source: Department of Geography, University of Nigeria, Nsukka

Statistics Nsukka, 2006). The predominant occupation of the people in Nsukka LGA is agriculture which is mostly small-scale based. A small proportion of them engage in trading while a reasonable number of them are in the civil service and private sectors. Recently, small scale fish farming is springing up in different towns of the area because of the good market demand for it. Fish farming in the area is becoming very attractive that even the traders and civil servants are beginning to engage in its part-time production.

This study employed a two stage multi-stage technique for selecting the respondents. In stage 1 , eight communities where catfish farming is predominant were purposively selected from the 18 communities that made up Nsukka LGA. These communities include; Nsukka town, Okpuje, Edeobala, Obukpa, Eha-alumona, Opi, Ibagwani, and Alor-uno. In stage 2, five (5) respondents were randomly selected from each of the eight communities, making a total of 40 catfish farmers.

Primary data were collected with the aid of well-structured questionnaires and personal interviews. The questionnaires were designed to capture relevant background information from the respondents, data on catfish production, the problems facing catfish farmers, and also data on the costs and returns of catfish business. Objectives $i$ and $i i$ which were to examine the socio-economic characteristics of catfish producers, and ascertain their management systems and practices respectively were analyzed using descriptive statistics such as mean, frequency and percentages, while objective iii which was to estimate the cost and returns of catfish production was realized using Net Farm Income analysis. The Net Farm Income is expressed as:

\section{NFI- GM - TFC (Per production cycle) GM - TR - TVC;}

where NFI is Net Farm Income, GM is gross margin, TFC is Total Fixed Cost, TR is Total Revenue, and TVC is Total Variable cost, all in
Gross margin is the difference between TR and TVC, while Net Farm Income (NFI) is the difference between GM and TFC. TR revenue was obtained by multiplying the average quantity of catfish sold with the average price. The fixed costs are however depreciated to obtain the actual value of the variable per production cycle. The straight line method was used to calculate the depreciation of the equipments, and the formular given as:

$$
\text { Depreciation }=\frac{\text { cost price-salvage value }(\mathrm{N})}{\text { Expected lifespan }(\text { years })}
$$

The outcome of the difference between GM and depreciated TFC signifies the profitability of an enterprise. A positive NFI shows that an enterprise is a profitable one and worth continuing with. A negative NFI signifies otherwise, that is, a loss and a business not worthy of emulation or one that requires a total overhaul.

\section{RESULTS AND DISCUSSION Socio-Economic Characteristics of Catfish Farmers}

Socio-economic features are critical components in social science research largely because of the fact that one's socioeconomic standing has significant impact on behavior, attitudes and perception towards issues. In this study, the elements of the socio-economic characteristics of Catfish farmers were considered necessary in recognition of their role in influencing the management and profitability of Catfish production. The factors considered include; gender, age, educational level, marital status, farming experience, and household size. Table 1 presents the result of the socioeconomic characteristics of the respondents.

\section{Gender}

The description of the respondents by gender as shown in Table 1 indicated a gender bias in catfish farming where there is male domination $(82.5 \%)$. This situation according to Ngeywo et al. (2015) is capable of discouraging female farmers from actively engaging in catfish farming activity, thus impacting negatively on catfish production since women are key actors in productive farm operations. This male dominating scenario in the production of catfish may also not be unconnected to the report of International Labour Organization 'ILO' (2016) which noted male domination and low female involvement in most paid ventures in many developing economies. Despite the increase in women's participation in developing economies, most women continue to feature more prominently in unpaid responsibilities than in income yielding ventures. The result of this study is also in line with the finding of Akinpelu et al. (2013) who reported that out of the 110 catfish farmers sampled in Oyo state, Nigeria, only 27 of them were female. Confirming this finding, Adelakun et al. (2015) in 
Table 1: Socio-economic Characteristics of the

\begin{tabular}{ll} 
Respondents & \\
\hline Variables & Percentage (40) \\
\hline Gender & 82.5 \\
Male & 17.5 \\
Female & 100.0 \\
Total & \\
Age (Years) & 42.5 \\
$<35$ & 42.5 \\
$36-55$ & 15.0 \\
$>55$ & 100.0 \\
Total & \\
Marital status & 35.0 \\
Single & 60.0 \\
Married & 2.5 \\
Separated & 2.5 \\
Widowed & 100.0 \\
Total & \\
Years spent in school & 7.5 \\
1-6 years & 50.0 \\
7-12 years & 42.5 \\
13-18 years & 100 \\
Total & \\
Household size & 7.5 \\
1-5 & 50.0 \\
6-13 & 100.0 \\
Total & \\
Catfish farming experience & 75.0 \\
1-4 years & 15.0 \\
5-9 years & 10.0 \\
>10 years & 100.0 \\
Total & Source: Field work, 2016; Value in bracket is the sample size \\
&
\end{tabular}

their assessment of catfish farming in Osogbo, Nigeria, reported $85 \%$ and $15 \%$ of male and female involvement in catfish farming, respectively. This shows that there is generally low involvement of women in Catfish production in Nigeria, a situation that may be limiting the profitability of the venture, and that is probably the reason for the generally low productive capacity of Catfish business in Nigeria. This is because women are known to increase the efficiency and productivity of any venture they are involved in due to their patient, persevering and meticulous approach to activities (FAO, 2011; Doss, 2018).

Age

Age is a key factor in productivity and profitability performance of the farmer (Ngeywo et al., 2015). Younger people or youths tend to be more energetic, adjust faster, and adopt new technologies, thus may be more productive than the elderly who may be more conservative. The findings showed that majority of catfish farmers fall within the age bracket of $<35$ and 55 years, hence could be regarded as young or youths. This shows that majority of the catfish farmers are in their prime youthful age, an indication of the potential for higher productivity that can translate to higher income and higher profitability.

\section{Marital Status}

Most of the Catfish farmers $(60 \%)$ were found to be married, $35 \%$ were single whilst $5 \%$ were either separated or widowed. How marital status interacts with productivity has been identified as an important policy issue, leading to debates over programmes to encourage healthy marriages. This is because empirical studies have shown that healthy marriages increase business profitability by about 20\% (Ahituv and Lerman, 2005). This finding suggests that marriage can reinforce earnings, productivity and profitability. Married people tend to have more household responsibilities than single people, thus pushing them to be more productive in their ventures in order to meet up with the demands of family life. Also, the ability of the household to supply the needed labour in the farm business depends to a large extent on the marital status of the households (Agbugba et al., 2014). The result of this study which shows that married people dominate catfish production is also an indication of the productive potential of the catfish business to support household livelihood.

\section{Number of Years in School}

Level of education plays an important role in influencing productivity and profitability. According to Staff (2012), median earnings increase with each level of education. Lareau (2003) noted that higher levels of education are associated with better economic and psychological outcomes (i.e., more income, more control, and greater social support and networking). Education plays a major role in acquitting more productive skills that will improve productivity and increase profitability as well as specific qualities that stratify people with higher socioeconomic status from lower socioeconomic status. The findings of this study reveal that majority of the catfish farmers were fairly educated as can be seen from Table 1 (50\% spent $7-12$ years in school, $42.5 \%$ spent 13 18 years in formal education). With this level of education, it is expected that catfish farmers should be more productive and the catfish production business more profitable. Where this is not the case, focus should be shifted to other socioeconomic factors that could constrain the profitability of catfish production business. Inoni et al. (2017) found that formal education had a positive and significant influence on the decision of farmers that led to higher productivity and profitability. Operators who spent more years in school acquiring formal education are likely to be more productive in catfish farming than their lesser educated counterparts. In fact, their results revealed that an additional year of education increases the likelihood of an individual's productivity by $4.8 \%$. This finding is also similar to those of Nkamleu and Adesina (2000) and Adeogun et al. (2008) who all found that level of education had positive and significant influence on farmers' productivity and profitability. 


\section{Household Size}

Size of household serves as a source of labour in most agricultural productions. Catfish production which requires a great deal of human effort from stocking, routine management, to harvesting will certainly benefit from higher household size. Our study found that most of the respondent $(50.0 \%)$ have household sizes within the range of six to thirteen (6 to 13) persons, while $42.5 \%$ has household size ranging from 14 to 19 . This result seems to reflect that of Nnadi et al. (2014) who found that about $35.56 \%$ of fish farmers in Delta state have an average household size of greater than six. Typical of many farming households in Africa, this result implies that many of the catfish farmers have relative large household size. Nkamleu and Manyong (2005) and Amsalu and de Graaff (2007) affirmed that larger households normally tend to have higher productivity as a result of availability of more labour, which most times are free, thus increasing the profitability of the venture.

\section{Catfish Farming Experience}

The farming experience distribution of the respondents is important in at least two different aspects; the first is increased productivity which comes with more experience, while the second is in the ability to diversify into different off-farm activities which comes with time, and also increases household income. Farming experience is very important as it gives more insight into the understanding of the dynamics of catfish production venture. It is expected that experienced farmers would be more productive. The distribution of the number of years of experience of the catfish farmers show that $75 \%$ have $1-4$ years of experience while only $10 \%$ have up to 10 years of catfish farming experience. This implies that majority of those in catfish production have not been in the business for a very long time. Oluwasola and Ige (2015) however posited that fish farming experience was a significant determinant of net income in catfish production.

\section{Catfish Management Systems Practices}

Catfish production and profitability are greatly affected by the management systems as well as the environment in which they are grown. According to Phuong et al. (2011), aquatic ecosystem is extremely dynamic, changing with management practices such as feed inputs, stocking density, pond size, etc. The effects of these management practices are even more pronounced in artificial systems like catfish farms where human beings influence what inputs are included to the culture environment. The result of catfish management systems and practices in Nsukka LGA is presented in Table 2.
Ansa (2014) noted that Catfish growth and survival are closely related management practices. More importantly, catfish are cold-blooded animals and their wellbeing depends on water quality which is affected by management practices. As shown in Table 2, 55\% of the respondents were operating ponds which were below 899 sq. meters while $45 \%$ were operating ponds that were bigger than 899 sq. meters. This implies that majority of the catfish farmers are still operating at small and medium scale level. Calculation of stocking density depends on a number of variables such as pond type, availability of water source, water volume, water management techniques, feed type, etc. (Abiodun, 2016). Investigation on the stocking densities of catfish showed that $30 \%$ of the respondents introduced 50-500 fingerlings into their ponds per production period, $40 \%$ introduced $600-1,000$ per production period while $30 \%$ introduced 1,000 and above fingerlings per production period.

Inquiries about the length of production cycle show that most $(62.5 \%)$ of the respondents have a production cycle of 6 months, $7.5 \%$ produce within 7 or 8 months while $2.5 \%$ have their production cycle extended to 9 months. This is in line with the study of Adeyemo et al. (2011) who found that it takes an average of eight months to produce catfish in Ibadan, Nigeria. The average market size of the catfish shows that a significant percentage $(77.5 \%)$ weighs between 1.3 to $1.5 \mathrm{~kg}$ and only 2.5 weighs above $1.5 \mathrm{~kg}$. This shows that their market size production is fairly good. Another major

Table 2: Catfish management systems and practices

\begin{tabular}{|c|c|}
\hline Variables & Percentage (40) \\
\hline \multicolumn{2}{|c|}{ Pond size (Sq Meter) } \\
\hline$<899$ & 55.5 \\
\hline$>900$ & 45.5 \\
\hline Total & 100.0 \\
\hline \multicolumn{2}{|l|}{ Stocking density } \\
\hline $50-500$ & 30.0 \\
\hline $600-1,000$ & 40.0 \\
\hline$>1,000$ & 30.0 \\
\hline Total & 100.0 \\
\hline \multicolumn{2}{|c|}{ Production period (months) } \\
\hline 6 & 62.5 \\
\hline 7 & 17.5 \\
\hline 8 & 17.5 \\
\hline 9 & 2.5 \\
\hline Total & 100.0 \\
\hline \multicolumn{2}{|c|}{ Average market size $(\mathrm{kg})$} \\
\hline $1-1.2$ & 20.0 \\
\hline $1.3-1.5$ & 77.5 \\
\hline$>1.5$ & 2.5 \\
\hline Total & 100.0 \\
\hline \multicolumn{2}{|l|}{ Feed type } \\
\hline Commercial feed & 80.0 \\
\hline Own formulation & 15.0 \\
\hline Household waste & 2.5 \\
\hline Agricultural waste & 2.5 \\
\hline Total & 100.0 \\
\hline \multicolumn{2}{|c|}{ Feeding frequency (daily) } \\
\hline $1-4$ years & 7.5 \\
\hline $5-9$ years & 80.0 \\
\hline$>10$ years & 12.5 \\
\hline Total & 100.0 \\
\hline
\end{tabular}


management factor affecting the profitability of catfish production is feed type. Nkwocha and Nkwocha (2013) noted that feed type, availability, and high price is a major obstacle to intensive aquaculture profitability in Nigeria, and recommends the use of cheaper locally available material for fish feed production. The result of this study shows that majority $(80 \%)$ of feed used by catfish farmers in the study area were commercial feeds, $15 \%$ make use of self formulated feeds, while a few $(2.5 \%)$ utilize household or agricultural waste for production. This implies that most of the catfish farmers use more expensive commercial feed which could affect their profitability.

\section{Profitability of Catfish Production}

The catfish farmers incurred several costs in the course of their production. In the short run, these costs include both variable and fixed costs of production. The variable costs involved in catfish production as articulated by Ugwumba (2005), Ugwumba and Nnabuife (2008) include catfish seeds (fingerlings), catfish feeds, labor, water, transportation and other miscellaneous costs. The average value of variable cost incurred by the catfish farmers per production cycle is presented in Table 3.

The average value of fixed cost is presented in Table 4. These are costs that last for more than one production cycle and it does not change within one production period, but can be altered in the long run. The straight line method was used to calculate the depreciation of the equipments. The salvage value was assumed to be zero because the equipment used by the fish farmers does not last for more than one year after which they are changed.

Table 3: Average value of variable cost per production cycle

\begin{tabular}{ll}
\hline Variable Cost & Value in naira (\#) per production \\
\hline & Cycle \\
Transportation & $29,342(5.8 \%)$ \\
Feed (kg) & $236,980.5(46.8 \%)$ \\
Water & $93,441.46(18.4 \%)$ \\
Treatment & $6,073.171(1.2 \%)$ \\
Labour & $43,365.95(8.6 \%)$ \\
Fingerlings & $97,287.8(19.2 \%)$ \\
Total variable costs & $506,491.171$ \\
\hline \multicolumn{2}{l}{ Source: Field survey, 2016; }
\end{tabular}

Table 4: Average value of fixed assets and their depreciation value

\begin{tabular}{llll}
\hline Fixed cost items & $\begin{array}{l}\text { Total } \\
\text { value(N) }\end{array}$ & Lifespan & Depreciation(N) \\
\hline Fish Pond & 334,805 & 15 & $\begin{array}{l}22,320.33 \\
(28.4 \%)\end{array}$ \\
Land & $120,276.44$ & 30 & $4,009.21(5.1 \%)$ \\
Wheelbarrow & $9,824.39$ & 3 & $3,274.80(4.2 \%)$ \\
Fish net & $25,747.32$ & 1 & $25,747.32(32.8)$ \\
Basket/buckets & 3960.98 & 1 & $3,960.98(5.0)$ \\
Boreholes/water & 278,500 & 15 & $18,566.67(23.7)$ \\
pump & & & \\
Broom & 597.561 & 1 & $597.56(0.8 \%)$ \\
Total Fixed cost & & & $78,476.87$ \\
\hline Source: Field survey 2016 & &
\end{tabular}

The fixed cost items are made up of depreciation values of water pumps (electric or fuel), borehole, concrete pond, earthen pond, land, machinery and equipment. The total cost of production for all the farms amounted to \$584968.041. Out of this amount, the total variable costs accounted for $\$ 506,491.171$ while the total fixed cost accounted for $\$ 78,476.87$. Again, cost of feeds alone constituted about $46.8 \%$ of this total cost figure, corroborating the findings of Nathan (2006), Ugwumba et al. (2006) that cost of catfish feeds accounted for over $60 \%$ of the total cost of production. By implication, catfish feed stands as the major ingredient required for catfish farming. This finding is also in tandem with El-Naggar et al. (2008) who concluded that feed costs represented $68.9 \%$ of the total production costs of fish.

Cost and return analysis was done using Gross Margin and Net Farm Income analyses. The variables analyzed using these analytical tools are the Total Revenue, Total Variable Cost and the Total Fixed Cost. The average total revenue accrued from the sale of mature catfish was utilized in calculating the cost and returns of catfish production. The analysis indicating total fixed cost (TFC), total variable cost (TVC), gross margin (GM), net farm income (NFI) are shown in Table 5.

Table 5: Cost and Returns structure for catfish farming in Nsukka area

\begin{tabular}{|c|c|}
\hline Items & Average value \\
\hline \multicolumn{2}{|l|}{$\begin{array}{l}\text { Revenue } \\
\text { (Average guantity sold x Average price) }\end{array}$} \\
\hline Average quantity of catfish sold & $2,655.409$ \\
\hline Average price per $\mathrm{kg}$ & \#850 \\
\hline Total Revenue of market size catfish & \#2,257,098 \\
\hline \multicolumn{2}{|l|}{ Variable Cost (\#) } \\
\hline Transportation & 29,342 \\
\hline Feed $(\mathrm{kg})$ & $236,980.5$ \\
\hline Water & $93,441.46$ \\
\hline Treatment & $6,073.171$ \\
\hline Labour & $43,365.95$ \\
\hline Fingerlings & $97,287.8$ \\
\hline Total variable costs & $506,491.171$ \\
\hline \multicolumn{2}{|l|}{ Fixed cost items (\#) } \\
\hline Fish Pond & $22,320.33$ \\
\hline Land & $4,009.21$ \\
\hline Wheelbarrow & $3,274.80$ \\
\hline Fish net & $25,747.32$ \\
\hline Basket/buckets & $3,960.98$ \\
\hline Boreholes/water pump & $18,566.67$ \\
\hline Broom & 597.56 \\
\hline Total Fixed cost & $78,476.87$ \\
\hline Total Cost (\#) & $584,968.041$ \\
\hline \multirow{2}{*}{\multicolumn{2}{|c|}{$\begin{array}{l}\text { Source: Field survey } 2016 . \\
\text { Gross margin = Total Revenue (TR) }- \text { Total Variable Cost } \\
\text { (TVC) }\end{array}$}} \\
\hline & \\
\hline \multicolumn{2}{|c|}{ Gross margin $=$ Total Revenue $(\mathrm{TR})-$ Total } \\
\hline \multicolumn{2}{|c|}{ Variable Cost (TVC); $\$ 2,257,098$ - $\$ 506,491.171-$} \\
\hline \multicolumn{2}{|c|}{ N1,750,606.83. Net Farm Income $=$ Gross Margin - } \\
\hline \multicolumn{2}{|c|}{ Total fixed Cost; $¥ 1,750,606.83-\mathrm{N} 78,476.87=$} \\
\hline N1,672,129.96 & \\
\hline
\end{tabular}


The gross margin and net farm income (NFI) from catfish production per production cycle (average of 7 months) are $11,750,606.83$ $(\$ 4,829.26)$ and $\$ 1,672,129.96 \quad(\$ 4,612.77)$ respectively. This indicates a profitable production cycle in the study area. Catfish farming has equally been adjudged a profitable venture in the studies conducted in, Lagos, Oyo and Kaduna States of Nigeria (Adeogun et al., 2007); Olagunje et al. (2007), and Kudi et al. (2008).

\section{CONCLUSION AND RECOMMENDATIONS}

This study analyzed the socioeconomic and management factors, and the profitability of Catfish production in Nsukka, area of Enugu State, Nigeria. Descriptive statistical tools such as frequency distribution tables and percentages were used to determine the socio-economic and management practices of catfish production in the area. Gross margin analysis and Net farm Income were used to estimate the costs and returns. The result of the study shows that Catfish production in the area is a profitable business venture, albeit there exist some socioeconomic and management constraints. To increase its profitability, large scale production should be embarked on, which will also allow for availability of catfish throughout the year and at a reduced price. This will also encourage more families to supplement their diet with catfish regularly in order to meet the recommended protein intake of 35 grams per day by Food and Agriculture Organization of the United Nations. It is recommended that prices of feeds and access to feeds by catfish farmers be regulated by the State Government in order to ameliorate the problems of high cost of feeds/inadequate supply of feeds to catfish farmers in the area. This will encourage more farmers in the study area to engage in commercial catfish production. Alternatively, catfish farmers should source for locally formulated feeds, which is often cheaper. This will reduce the overall cost of production and consequently increase their profitability. Catfish farmers should also be encouraged to form viable co-operatives to help them easily access incentives from the government and other development agencies who prefer giving assistance to cooperatives or associations of farmers instead of individual farmers. Adequate trainings and seminars should be held at intervals to update catfish farmers' knowledge on catfish farming so that they can have access to improved methods and technologies of catfish production. Also, further research is recommended to ascertain the effect of type of pond system, and the level of intensive system used in catfish production on the profitability of catfish production.

\section{REFERENCES}

Abiodun E. (2016). Profitable Fish farming (4 ${ }^{\text {th }}$ Ed.). Anders Norem Press, p. 15

Adekoya B.B. and Miller J.W. (2004). Fish cage culture potential in Nigeria-An overview. National Cultures, Agriculture Focus, 1 (5), 10-18

Adelakun K.M., Amali R.P., Ogundiwin D.I. and Bakare K. (2015). Assessment of catfish farming in Osogbo (Nigeria) and its environs. Peer $J$ PrePrints, 3, 17-27

Adeogun O.A., Ajana A.M., Ayinla O.A., Yarhere M.T. and Adeogun M.O. (2008). Application of logit model in adoption decision: a study of hybrid clarias in Lagos State, Nigeria. American-Eurasian Journal of Agriculture and Environmental Science, 4 (4), 468-472.

Adeogu O.A., H.K., Ogunbadejo O.A., Ayinla A., Oresegun O.R., Oguntade A.T. and William S.B. (2007).

Urban Aquaculture: Producer perceptions and practice in Lagos State, Nigeria. Middle-East J. Sci. Res., 2, 21 27

Adeyemo O.K., Ganiyu O.I. and Olugasa B.O. (2011).Comparative evaluation of productivity and cost effectiveness of Catfish fingerling production in Earthen Pond and Recirculation System in Ibadan, Nigeria. Nigerian Veterinary Journal, 32 (1), 5-8.

Agbugba I.K., Ihemezie E.J. and Adam E.A. (2014). Informal sources of financing climate change adaptation amongst crop farmers in Nigeria. International Journal of Agricultural Science, Research and Technology (IJASRT) in EESs, 4 (1), 7-13.

Ahituv A. and Lerman R. (2005). How Do Marital Status, Wage Rates, and Work Commitment Interact? Institute for the Study of Labor. Discussion Paper No. 1688

Akinpelu O.M., Ayeloja A.A., George F.O.A., Adebisi G.L., Jimoh W.A. and Idowu S.D. (2013).Gender Analysis of Processing Activities among Commercial Catfish Processors within Ibadan Metropolis, Oyo State South-Western Nigeria. Journal of Aquaculture Research \& Development, 4, 176-181.

Ali E.A., Gaya H.I.M. and Jampada T.N. (2008). Economic analysis of fresh fish marketing in Maidugri Gamboru Market and KachallariAlau Dam Landing Site of Northeastern Nigeria. $J$. Agric. Soc. Sci., 4, 23-26

Amao J.O., Awoyeni T.T., Omonona B.T. and Falusi A.O. (2009). Determinants of poverty among fish farming households in Osun State, Nigeria. International Journal of Agricultural Economics and Rural Development, 2 (2), 14-25.

Amsalu A. and de Graaff J. (2007). Determinants of adoption and continued use of stone terraces for soil and water conservation in an Ethiopian highland watershed. Ecological Economics, 61 (3), 294-302.

Ansa E.J. (2014). Challenges and production process of catfish hatcheries in the Niger Delta region of Nigeria.Technical report. Nigerian Institute for Oceanography and Marine Research

Central Bank of Nigeria. (2017). Annual Report 
Cheeke P.R. (2002). Rabbit feeding and nutrition. Rabbit research centre, Department of Animal science, Oregun state University, Corvallis, Academic press Inc, p.66

Department of Geography, University of Nigeria, Nsukka (2015). Map of Nsukka Agro-ecological zone showing sampled areas.

Doss C.R. (2018). Women and agricultural productivity: Reframing the Issues. Development Policy Review, 36 (1), 35-50

Enugu state Agricultural Development Programme (2008). ENADEP Archives, p. 21

El-Naggar G., Nasr-Alla A. and Kareem R.O. (2008). Economic analysis of fish farming in Behaira governorate of Egypt. 8th international symposium on Tilapia in aquaculture, Central Laboratory for Aquaculture Research, Abbasa, Ministry of Agriculture and Land Reclamation, Cairo, Egypt, pp. 693-707.

Esu B.B., Asa U.A. and Iniedu M.O. (2009) Costs and returns of fish production using earthen ponds in Akwa Ibom State, Nigeria. Nigerian Journal of Agriculture, Food and Environment, 5 (4), 26-29.

Fagbenro O.A., Adedire C.O., Owoseeni E.A. and Ayotunde E.O. (1993). Studies on the biology and aquacultural potential of feral catfish, Heterobranchusbidorsalis (Geoffroy Saint Hilaire 1809) (Clariidae). Tropical Zoology, 6, 67-79.

FAO (2011). The role of women in agriculture. ESA Working Paper No. 11-02. Agricultural Development Economics Division of the Food and Agriculture Organization of the United Nations

FAO. (2005). Regional Review on Aquaculture Development in Sub-Sahara Africa. FAO Fisheries Circular No. 1017/4 pp 1-23

FAO. (1991). Fish for Food and Employment. Food and Agriculture Organization, Rome, Italy Global Agriculture Information Network, Report Number N17026.

F.D.F. (Federal Department of Fisheries). (2007). Fishery Statistics, FDF, Abuja, Nigeria.

Federal Office of Statistics Nsukka (2006). Annual Bulletin

FNB: Food and Nutritional Board. (2005). A Report of the Panel on Macronutrient, Subcommittees on upper Reference Levels of Nutrient and interpretation and Uses of Dietary Reference Intakes, and the standing Committee on the scientific Evaluation of Dietary, p. 122

Igwe K.C. and Onyekwere O.N. (2007). Meat Demand analysis in Umuahia Metropolis Abia State. Agricultural journal, 2 (5), 550-554.

Iheke O.R and Nwagbara C. (2010). Profitability and viability analysis of catfish enterprise in Abia Inoni O.E., Ekokotu P.A. and Idoge D.E. (2017). Factors influencing participation in homestead catfish production in Delta state, Nigeria. Actaargiculturae Slovenica, 110 (1), 21-28

International Labour Organization (2016). Women at Work: Trends 2016,p.7

Kudi T.M., Bako F.P. and Atala T.K. (2008). Economics of fish production in Kaduna State, Nigeria. ARPN Journal of Agricultural and Biological Science, 3 (6), 17-21.

Lareau A. (2003). Unequal Childhoods: Race, Class, and Family Life. University of California Press, p. 21
Miller J. and Atanda T. (2007). Fish-farming village. A Model for Replication from Nigeria? Unpublished Technical Note.

Ngeywo J., Basweti E. and Shitandi A. (2015). Influence of Gender, Age, Marital Status and Farm Size on Coffee Production: A Case of Kisii County, Kenya. Asian Journal of Agricultural Extension, Economics \& Sociology, 5 (3), 117-125.

Nkamleu G.B. and Manyong V.M. (2005). Factors affecting the adoption of agroforestry practices by farmers in Cameroon. Small-scale Forest Economics, Management and Policy, 4 (2), 135148

Nkamleu G.B. and Adesina A.A. (2000). Determinants of chemical input use in peri-urban lowland systems: bivariate probit analysis in Cameroon. Agricultural Systems, 63, 111-121.

Nandi J.A., Gunn P., Adegboye G.A. and Barnabas T.M. (2014). Assessment of fish farmers' livelihood and poverty status in Delta State, Nigeria. Agriculture, Forestry and Fisheries, 3 (5), 427-433.

Nwokocha J. and Nwokocha N. (2013). Development of aquacultural feeds from locally available feedstuff: A giant step towards food security in Nigeria. Int $J$ Acad Res Prog Educ Develop, 2 (3), 153-175.

Oladimeji Y.U. (2017). Trend in fish production parameters in Nigeria and its total estimated demand: empirical evidence from fish production. J. Anim. Prod. Res. 29 (1), 410-418

Olagunje F.I., Adesiyan I.O. and Ezekiel A.A (2007). Economic Viability of Cat Fish Production in Oyo State, Nigeria. J. Hum. Ecol., 21 (2), 121-124.

Oluwasola O. and Ige A.O. (2015). Factors determining the profitability of Catfish production in Ibadan, Oyo State, Nigeria. Sustainable Agriculture Research, 4 (4), 57-65.

Orusegun A, Oguntade O.R. and Ayinla O.A. (2007). A review of catfish culture in Nigeria. Nig $J$. Fisheries. 4 (1), 27-52.

Phuong N.T., Hao N.V., Tam B.M., Lam P.T., Son V.M., Nhut N., Long D.N., Thuy-Nguyen T.T., Gooley G.J., Ingram B.A. and Silva S.D. (2011). Better Management Practices for Striped Catfish (tra) Farming in the Mekong Delta, Viet Nam. Vietnam Ministry of Agriculture and Rural Development pub, p.1

Staff A. (2012). Education and Socioeconomic Status. American Psychological Association, p.52

Ugwumba C.O.A. and Chukwuji C.O. (2010). The economics of catfish production in Anambra State,Nigeria: A Profit Function approach. J. Agric. Soc. Sci., 6, 105-109.

Ugwumba C.O.A. and Nnabuife E.L.C. (2008).Comparative Study on the Utilization of Commercial Feed and Home-made Feed in Catfish Production for Sustainable Aquaculture. Multidiscipl. J. Res. Dev., 10, 164-169

Ugwumba C.O.A. (2005). The Economics of Homestead Concrete Fish Pond in Anambra State, Nigeria. African J. Fish.Aquacult.,4, 28-32

Ugwumba C.O.A., Ugboaja M.O. and Orji E.C. (2006). Sustainable Catfish Seeds Production in Anambra State. African J. Fish. Aquaculture, 5, 50-65 